This is an open access article under the CC BY-NC-ND license (https://creativecommons.org/licenses/by-nc-nd/3.0/) Issue III, November 2020

ISSN 2707-9481

ISBN 978-601-323-207-2

https://doi.org/10.31643/2020.016

\author{
Dinara Zhulamanova \\ Abai Kazakh National Pedagogical \\ University, Kazakhstan \\ E-mail: zhakdinara@mail.ru \\ ORCID ID 0000-0001-6996-1297
}

\title{
Importance of managing the professional development of young teachers
}

\begin{abstract}
The article considers the importance of managing the process of professional development of young teachers in the education system of Kazakhstan. The author focuses on the introduction of a modern approach to the implementation of personnel policy in educational organizations, as well as on the method of training young professionals for schools and further development of the competencies of a novice teacher. In addition, the author suggests a number of measures for the successful adaptation of future teachers in the framework of state preparatory programs. The article considers the effectiveness of the "mentoring" function in modern realities, as well as the team approach in the process of becoming future teachers.
\end{abstract}

Keywords: young teacher, mentoring, professional development, personnel management, personnel policy.

\section{Introduction}

The main goal of the education system of the XXI century is to train a competitive, highly qualified specialist. If we consider the school as the main organization and environment, then the person who leads to this goal is the teacher. According to the requirements of modern times, the teacher must be an educated, improving, comprehensively developed and creative person.

The activity of the teacher is aimed at the future and focused on the future achievements of children. A special feature of pedagogical activity is the ability of the teacher to find ways to the heart of each student, the ability to create favorable conditions for the development of the abilities of each child. The most important thing is that the teacher can help the student realize himself as a person, awaken in him the desire to know his inner world and life [1, p.23].

\section{Main research part}

Young teachers are the future core of the school's workforce. A young specialist with his own characteristics and new ideas, brings new values in any field. The time of formation and adaptation to the profession is the most vulnerable period in the career of a teacher. One of the main goals of professional development of young teachers is to improve and develop their skills. Young teachers are subject to the same requirements as colleagues with many years of experience. Students, their parents, and the administration also expect young teachers to have an impeccable professional approach to their work. But young teachers themselves need the attention of experienced colleagues and managers. In this regard, management, organizational and control actions are carried out by the administration. Assistance should be provided in improving professional skills and developing creativity among young teachers. Therefore, managing the process of professional development of young teachers is an urgent problem.

The success of the education system in any country depends on the quality of teacher training, their further professional growth and creative development. It takes time to develop the qualities of a qualified 
specialist. However, it is necessary to update the personnel structure of enterprises by attracting new employees in the field of education, ensuring the continuity of generations. Young teachers are being hired. Teachers who have worked for many years are replaced by young specialists, thus replenishing the personnel corps of schools. In the educational space, every year a large number of young teachers participate in the program of entering the teaching profession, i.e. in the process of professional development of young teachers. This program is an intra-school event aimed at training, supporting and maintaining interest in the work of graduates of pedagogical universities, young teachers. The program is the main stage in the process of continuous professional development, in which they are gradually included in the educational program [2].

Based on the definition of "young teacher", scientists associate it, first of all, with the period of "youth". Namely, youth as youth, the younger generation, youth. Young people are a group of society that has a large labor potential and is able to ensure the progressive development of the country. A young teacher of an educational institution is a person who has graduated from a higher or special pedagogical educational institution, regardless of age, who has worked for three years after training in the received specialty and is starting an independent professional activity, forming their professional qualifications. To ensure an effective process of professional development of young teachers, it is necessary to create the following conditions (resources): a) scientific and methodological conditions - ideas necessary for the development of the acquired knowledge, b) personnel conditions - the presence in the organization of education of persons prepared to work with young teachers; C) material and technical conditions; d) financial conditions; e) regulatory conditions; f) motivational conditions; f) temporary conditions [3].

Professional development of a young teacher is the key to the development of the younger generation, i.e. society and its moral foundations. Therefore, the organization of education requires a unified system of tools to facilitate the process of professional development of novice teachers. Thus, professional development is a certain period characterized by declines and rises, conflicts and crises associated with the interaction and relationship of factors of personal and professional development. The process of professional development of young teachers requires planning, organization, motivation and control. We carry out these actions through the general management [3].

HR management is one of the main components of modern management. HR management is a practical activity aimed at providing the organization with qualified specialists and rational use of personnel who are able to perform its assigned labor functions efficiently.

Personnel management in educational organizations is carried out by performing the following functions:

- Search for teachers and adaptation of young teachers, as well as promoting their professional development. Familiarization of young teachers with the labor collective and the specifics of work, if any.

- Development of plans, programs for training and development of teachers, conducting rapid assessment, organization of teachers ' work and their motivation.

- Development of a strategy for the development of the school as a whole.

We pay special attention to personnel management, managing the process of professional development of a young teacher. After all, managing the process of professional development of a young teacher is an active influence on the factors that determine its development, as a result, reducing adverse conditions. Management allows the process of professional development to be consistent and appropriate, as well as isolated and prevented from the destructive phenomena of external situations. Using the internal resources of a young specialist, a young teacher is transferred from managing them to the "self-management" mode. We know that the professional development of young teachers depends on several factors. Accordingly, the role, position of the young specialist, the rate of adaptation, which ultimately affects the degree of entry into the school team, is established.

As A. S. Makarenko said: "Dozens of young teachers worked with me. I became convinced that no matter how successfully a person graduated from a pedagogical university, no matter how talented they are, and if they do not learn from experience, they will never be a good teacher, I personally studied with experienced teachers". A system called mentoring allows a young specialist to receive practical and theoretical support from an experienced specialist. The mentoring process affects the interests of at least three subjects of interaction: the young teacher, the mentor and the school administration. The mentor shows that the teacher must properly conduct classes, any educational process. In addition, the young specialist plans the next working day, helps to create a plan and structure of the training process, helps in choosing the 
most appropriate training methods, gives advice when preparing tasks. He can answer any questions that arise [4].

The purpose of mentoring is to provide support, guidance and advice to teachers to enable them to enhance their teaching skills to develop professionally. Mentoring works best when it is carried out as part of a structured developmental programme. It can involve all or any of the following [5]:

- identifying developmental needs and interests

- identifying strengths and weaknesses

- action planning

- observing lessons and arranging peer observations

- reviewing progress

- coaching, for example, on aspects of teaching practice.

In other words, one of the methods of continuous professional development of a teacher is mentoring. Namely, mentoring in building its individual educational and professional trajectory. In addition, the main principle of the mentoring process is not the correction of mistakes of a young specialist, but the principle of preparing young teachers to overcome difficulties, professional formation and development. In this connection, Goethe said: "If you treat a person according to what he is, he will remain as he is. If you treat a person according to what they can and should be, they will become what they can and should be".

\section{Conclusion}

In Kazakhstan, the experience of mentoring is widely used in managing the process of professional development of young teachers. Therefore, in Kazakhstan, the state program for the development of education and science for 2020-2025 states that mentoring will be funded in the future in order to develop mentoring [6]. Thus, the management of the process of professional development of a young teacher is a systematically organized event of competent persons in order to support the successful transition from theoretical knowledge to practice. This involves concepts such as management, planning, organization, assistance, control, and orientation.

Cite this article as: Zhulamanova D. (2020) Importance of managing the professional development of young teachers. Challenges of Science. Issue III, 2020. Pp.: 115-117.

https://doi.org/10.31643/2020.016

\section{Refrences}

1. Taubayeva Sh. T., Imanbayeva S. T., Berikkhanova A. E., (2017). Pedagogika [Pedagogy], Almaty. Таубаева Ш.Т., Иманбаева С.Т., Берикханова А.Е. (2017). Педагогика, Алматы

2. Zhamantayeva K. K., Danina E. N. (2019). Features of the formation of professionalism of a young teacher in the conditions of updating the program of educational content. [Electronic resource]. URL: http://zkoipk.kz/nconf2019/1-section/4834conf.html.

3. Podkorytova G. I., Managing the process of professional formation of young teachers [Electronic resource]. URL: https://www.pedopyt.ru/categories/19/articles/1371

4. Zholdasova A. A., (2019) Organization of support for young specialists in school [Electronic resource] URL: http://zkoipk.kz/kz/nconf2019/2-section/4796-conf.html

5. Introduction to supporting and mentoring teachers [Electronic resource] URL: https://www.teachingenglish.org.uk/article/introduction-supporting-mentoring-teachers

6. State program of development of education and science of the Republic of Kazakhstan for 2020-2025 [Electronic resource] URL: https://www.zakon.kz/5002441-utverzhdena-gosudarstvennaya-programma.html 